\title{
Susie Saavedra
}

usie Saavedra was recently promoted to Vice President for Policy and Legislative Affairs at the National Urban League Washington Bureau. Prior to this role, she served as Senior Director for the same department. Specifically, Ms. Saavedra is the League's chief education and health policy officer, a responsibility she has held since 2013. She offers over 15 years of federal legislative, policy, and political experience along with a passion for advancing social and economic justice. Before joining the National Urban League, Ms. Saavedra spent a decade working in both the United States House of Representatives and United States Senate for four Members of Congress, as a Legislative Aide to former Senator Hillary Clinton, and as a Legislative Director for Representatives Karen Bass, Al Green and Joe Baca. She also promoted diversity in the halls of Congress as former President of the Congressional Hispanic Staff Association (CHSA) and has advocated for expanding opportunities for Hispanics in higher education as a governing board member of the Hispanic Association of Colleges and Universities (HACU). Ms. Saavedra is also the Vice President of the Hispanic Lobbyists Association which is dedicated to building diversity in the government relations profession. She holds a Master of Public Administration degree from George Washington University and a Bachelor of Arts degree from the University of Denver. 
Policy Perspectives: You currently serve as the Vice President for Policy and Legislative Affairs at the National Urban League's Washington bureau. Can you tell us a little bit about what the National Urban League does and what your role there entails?

Susie Saavedra: The National Urban League was founded in 1910 and our mission focuses on economic empowerment for African-Americans and other underserved communities. We operate through a network of 88 affiliates which are all sovereign 501(c)(3) nonprofit charity organizations that provide direct services in a wide variety of areas including education, health, housing, entrepreneurs, and job training. The work that we do is grounded in making sure every individual in our community has access to the tools to be self-reliant and to either get out of poverty and into the middle class or achieve their level of economic prosperity. The National Urban League acts as national intermediary that provides support to this network of affiliates. We have roughly 110 employees, including about 10 here at the Washigton Bureau. We were created in the 1960s during the Civil Rights Movement when our then-President and CEO Whitney $\mathrm{M}$. Young realized that in order to advance change, we needed a presence and voice in Washington because this is where the policymakers were, where laws were being made, and our voice represented a movement that was not being heard. So, we created an office with an executive director and maybe one staff person. Since then we've been able to build out to now a new executive director who also serves as the senior vice president for policy. We now have a Vice President for Advocacy, which is a relatively new position for Urban League. My previous position as Senior Director was created about two-and-a-half years ago. So, I'm officially the number two policy person in the office. But I functionally oversee the policy team and that is composed of a Senior Director for Civil Rights and Workforce Policy, a Director for Financial Services Policy, two managers for education and health policy, and a telecom and telecommunications fellow, and interns occasionally. I still sort of serve as the lead education and health policy person. But now we have a team because we have a large education policy and advocacy program, which is interesting because not a lot of civil rights organizations do the type of work that we do in education reform and innovation. So that program essentially revolves around our building the capacity and providing technical assistance support to Urban League affiliate leaders to enhance their ability to advocate on education equity and excellence issues in their state and local areas. We have a number of affiliates that work hand in glove with their state departments of education, and their local departments of education. They do this while navigating the politics of education through partnerships, coalitions with a variety of different players from chambers of commerce, their local mayor, their local legislature to other sister civil rights organizations and groups serving communities of color. So that's who the National Urban League is. We also publish a national report on the state of Black America. And that essentially includes an equality index. It's a temperature check on how African-Americans and Hispanics are doing compared to Whites in America. We compare equality along several indices including education, health, civic engagement, criminal justice issues, and a few other factors. The Hispanic index was put in seven years ago, however, we've had an equality index for 10-15 years. That research is a measuring stick for how far we've come and how far we need to go in ensuring all Americans have opportunity to achieve the American Dream.

PP: Does the Urban League's health portfolio focus on health disparities between people of color and Whites, like diseases or areas that impact communities of color? What are the big issues that are focused on? 
SS: Four or five years ago, we did some strategic planning organizationally to come up with a set of economic empowerment goals that we wanted to measure our progress against. Between then and 2025, our health economic empowerment goal is to ensure all Americans have access to quality, affordable healthcare solutions. We have in our State of Black America report a list of indicators in health that paint a picture of our nation's health for Black Americans. It measures disparities such as high rates of obesity, diabetes, child maternal health, teen pregnancy rates, and some other indicators. So, it's a Black-White index and Hispanic-White index. We're also a member of a coalition of diverse stakeholders. There are about 150 national state and local health equity-focused organizations. We've worked collaboratively with these organization on a signature heath disparities bill that's been introduced in Congress since 2008. Every two years, one arm of the professional tri-caucus (Hispanic, Black, Asian and Pacific-Islander caucuses) introduces this signature piece of legislation to reduce and eliminate health disparities. It's basically a vision for the types of policies that are needed to move the needle in improving health outcomes for all Americans.

\section{PP: You've spent the bulk of your career thus far on Capitol Hill working for several Democratic members of Congress, including Hillary Clinton. Was a career working in politics and public service something you'd always known you wanted to do?}

SS: Yes. I went to college at the University of Denver. I did work-study throughout college as a Pell Grant student. My work-study was at a nonprofit called La Raza, a Latin American research and service organization. They helped to provide services and advocacy for Hispanic in the Denver metro. I also worked for a community center in the west part of Denver and helped provide adult ESL centers and spent time in the community. Growing up in a military community gave me a keen sense of social and economic differences. I lived in eight different states growing up and remember moving from Columbia, South Carolina to El Paso, Texas for my senior year of high school. They are two completely different towns. I grew up in a working-class family. We had food stamps and lived in military housing. I always remember thinking that we didn't have as much as other kids; we didn't have a nice house, I didn't grow up having Banana Republic and J. Crew; I might have gone to Target instead. Columbia was either White, Black, and other, but we all got along. There were poor and super rich, but the majority were middle class. In El Paso, I think went to the worse school in the county. I remember talking to my guidance counselor everyday because the school didn't have enough resources. We had to rent our textbooks and I was in the band and we didn't have enough uniforms to go around. My class started out with 1200 and graduated 330; almost two-thirds of the kids dropped out. What really hurt me and gave me an "aha" moment was that 90 percent of the kids were Hispanic. It really touched a nerve---it ignited an anger, a passion, a feeling that the system had let my people down, people that looked like me. I had an affinity toward them. To see, hear, and interact with classmates that were not going to college and were not seeing a future different from their current existence in the city of El Paso really hurt me. I saw intergeneration poverty. I had this vision of a community abandoned and I was living in it. This was draining and made me very sad. When I got that whole experience, it illuminated for me that this is what racial discrimination and segregation were like for that community and that those kids were left behind. I thought "that shouldn't happen in America." I saw things that no 17-year-old should see, and I saw the same thing in college, but in a different scenario. I went to a private institute, I was one of two Hispanics; there were one or two Black students in my classes. Those kids that were in my classes were not well-off 
financially. I saw a situation where you have wealthy students that were predominately white, poor student show were primarily of color, and a gap in the type of supports, commitment and inclusion efforts on campus. I felt like a stranger on campus---like I couldn't fit in. None of my teachers were of color. When we talked about issues that impact people of color, it was a very awkward and uncomfortable. I had a constitutional law class and the professor employed the Socratic method as a part of his teaching style. One day, the topic was on affirmative action. He was putting forth the argument that affirmative action has not met its desired, intend outcome and that we should scrap it. Then he asked what we thought. I am thinking, "but those kids (there were a lot of smart kids in those schools) for whatever reasons, are not going to college whether it be by choice, misinformation, or lack of resources. We should be doing more to close that gap so that more students of color get into college." You asked if I has passion for nonprofit service; I think that I delivered that passion through my experience growing up in a military family and witnessing economic disparities along racial lines, and seeing really disheartening examples of segregated schools in a community left behind by a system that neglected them.

PP: In addition to your roles in the personal offices of members of Congress, you were also President of the Congressional Hispanic Staff Association, which works to build a pipeline of Hispanic staff at all levels on the Hill. Did you see any progress being made during your time on the Hill in terms of staff diversity? What do you think still needs to happen in order to increase staff diversity, particularly in senior positions?

SS: This is a timeless, age-old question and it is disheartening that we are barley able to move the needle in 2018. Back in 2009, I was one of nine Hispanic legislative directors in 535 offices. The Senate maybe had one or two Legislative Director (that's the number 2 position in a congressional office) and maybe Hispanic two chiefs of staff. The Senate maybe had one or two black chiefs of staff and maybe one or two chiefs of staff. Those numbers haven't changed. We've gotten a few more Black and Latino members of Congress. But the issue of staff diversity is pervasive. We as an organization have tried to shine a spotlight on it. We partnered with the Joint Center for Economic Studies, last year I believe, to do some research on it. They actually have a dedicated staff person focused on this from the advocacy perspective, and we support them on that level. Senate Democratic Leader Schumer, under Harry Reid's leadership, created a senate diversity office which created a dedicate staff person responsible for working with democratic senate offices to diversify their staff and leadership. The House never did anything like that. I think the best thing the House did create a resume bank. However, without having a dedicate staff person to work with staff to make sure their resumes are presentable, do mock interviews, and help them understand the role their interviewing for, you're just throwing resumes in a black hole. So the Congressional Hispanic Office Association partnered with the Senate Diversity Office to field resumes of qualifies candidates. But before they do, they prepare the staff to be ready for that call. We, the National Urban League, send resumes, so we hear from interested candidate who are trying to transition to different offices or roles, and we provide support to different offices that reach out looking for qualified candidates of color. So, the head of this office served as Senator Landry's Chief of Staff in 2013, and he was the only Black Chief or Democratic Black Chief of Staff in the Senate; he's also very passionate about these issues. I think last year there was a lot of push from outside advocates like the National Urban League highlighting the attention on the disparities and lack of diversity in staff and leadership roles in Congress. We know that leaders influence the member of Congress whether 
its drafting bills or recommendations on votes for the chambers. So, we think it's important that those votes and recommendations be influenced by people that look like America. It's no longer acceptable to not have staff on Capitol Hill that can represent the voices in our communities back home. So we're doing all we can to change it.

If I'm not mistaken, Senator Schumer is pushing for the Rooney Rule to be used throughout the hiring process at least throughout Democrats in the Senate. We think this is a good step because part of the problem that we see is that most chiefs of staff are White, and most chiefs get their advice from White lobbyists. It's a circle of influence in the same community. Our hope is that by encouraging staff to at least consider candidates of color for leadership roles, that they will consider reaching out to lobbyists or organizations that represent communities of color so that they can widen the poll of candidates. I think a lot of it has to do with relationships and being able to get out of your comfort zone. We're helping by being open to offering ourselves as a resource. We're not here to attack these offices for not hiring people of color; we want to help. Honestly, civil rights work is like that too. You have to find the right ways to connect with people in advocacy, and in my experience it starts with building trust. In civil rights work, I learned that is there's a lot of work to be done to build trust between communities of color and those that serve them because trust has been broken many times. So, when we do this work in education, we have to remind leaders of that. Were not here to protest just for the sake of protesting, we're here to inform you on the issues facing our communities with the hopes that we can work collaboratively, as a team, in relationship with each other, for the same cause. That's a cultural change.

PP: What made you decide to leave the Hill after more than a decade to come to the National Urban League where you now find yourself trying to influence Congress from the outside? Now that you've worked in Congress and advocated to Congress, do you find that you prefer being on one side or the other? Do you see yourself go back to work on the Hill in the future? SS: Again, I was raised in a military family and my father served as an enlisted soldier in the army for 27 years. We didn't grow up reading The New York Times everyday. We grew up talking about normal family with issues like needing lunch money, or school supplies, or a new pair of jeans. So, when I got to Capitol Hill, it was after I had spent four years in Denver working in the community, but I didn't have political experience under my belt. I had a frame of mind with a passion to serve that propelled me to want to be in the system that had the power to crate change across the nation. So, when I worked for Hilary or all the other members, I was grounded in the belief that my purpose was greater than me, the leader, the state, district; I was driven by my desire to serve people in need. So that's what I did on Capitol Hill. I worked for members of Congress who were aligned with similarly believe that we could create policies that reinstitute positive social and economic growth in the comminutes that we serve. So, when I gained extensive experience on Capitol Hill, I was looking for another way to continue that mission. When I heard about the senior policy director position at the National Urban League, it was a natural fit. It's a continuation of the work, but it's more focused on those communities across the country. I am now able to work nationally for 300 urban communities across the country.

PP: Why did you decide to pursue an MPA degree, and what made you choose GW specifically? SS: So, back then, I just knew that I wanted to do more to influence our nations education 
system. I didn't know how, but I had run into people in - at that time - the Clinton Administration, who were worked in the White House, and it inspired me to a higher level of service - something outside of Denver with a national level of impact. So, I came to DC the summer of '99 because I was selected to participate in the Ron Brown Fellows Program. We learned a little about advocacy. That was my first time learning about the different advocacy associations and nonprofits that were in DC but were serving communities across the country. All of the leaders in the program that were speaking to us said "based on what you're telling me - that you want to create educational change on a nationwide - you should get a master's degree in public administration or public policy and go to school in DC." So, I interviewed and fell in love with Dr. Newcomer, the program, and how she described it to me. I'd applied to other schools in different places, but I just kept thinking, "if I'm going to create positive change in our nation's education policies, then I should be in the place where they make those laws and figure it out as I go."

PP: That's a common theme that we've heard from all the alumni we've interviewed! Its seems cliché because all the GW brochures highlight its location in the heart of the nation's capital, but it's actually so true.

SS: I was recently discussing this with someone. If I had went to another school, I don't think that I would have access to the same leaders on a day-to-day basis as I did here. I am a firm believe that everybody needs a mentor and that we are guidance in our path by the people that we meet and interact with. The quality of those interaction here is different than other in places.

PP: Where and how have you found you've been able to apply the knowledge, skills, and/ or experiences from your time at GW to your professional life? What aspects of the MPA program in particular do you think you've found most valuable?

SS: I remember the federal budgeting class; I use that almost everyday. It was a good primer for learning about the congressional appropriation process. A lot of what impacts public schools is a lack of resources whether its teachers, technology, advanced courses. A lot of that is acquired through funding. Being able to understand how federal dollars get appropriated and the role congress, the administration, and the agencies play is very important in knowing how to influence policy. That's definitely one course that I felt was very helpful.

I've travel to many counties and have an appreciation that we as a nation put so much focus, energy, and studying how to improve systems of government so that they can have the greatest impact for the greater good. You have a whole bunch of countries that are not investing time, money, and resources on this. I think that I was able to go through GW's program and gain a sense of awareness of how integrated these systems are because we don't operate in silos, especially here in DC. You have so much infrastructure working collaboratively or complementary. Case in point, when we were reauthorizing the Elementary and Secondary Education School Act in 2015, Congress had their version of their proposal for reauthorization, the civil rights community had their principle and priorities that they wanted to make sure was included, and the Obama Administration had their own priorities. It was interesting to see because we learned some of this in our MPA program. Just being able to work together 
with these very different levels of government and levels of influence and see all of it work out in the end, gave me a stronger foundation throughout career because of the MPA program. The program helped me to put into perspective that we're all interconnected how relates to the nonprofit, advocacy and congressional work that I've done. I was able to make logical connections with the work which made it easier for me to transition to the Hill. I also loved Lori Brainard's class.

PP: What advice would you give to current students at Trachtenberg who are thinking about the next step in their careers? Are there things you wish you'd known or that you'd done when you were working on completing your degree?

SS: I remember being in this very scary place months before graduation thinking "I'm going to be unemployed soon," and that I need to create a strategy for how I'm going to come across job vacancies, apply, revise my resume, look at job descriptions, decide what field I want to focus on, the kind of job I wanted, and determine how much time I was going to give myself to find a job. I ended up just throwing my resume out there; at a lot of the places I didn't really know how I would fit in. However, I came to DC with a small network through my fellowship on Capitol Hill I knew one or two people from that program who had a vested interest in seeing me grow. They were from the National Association of Latino Elected and Appointed Officials (NALEAO). Their mission is to build a pipeline of Hispanic elected officials. They had a vested interested in diversity the halls of Congress as well. That aside, the way I got my job with Hillary is because the director of this program forwarded me the vacancy announcement for that position. Then the rest fell into place. I was also able to have multiple conversations and informational interviews with different people who shared what they did with, gave me other contacts to reach out to. I think you just have to be open to learning about all the jobs that are available and build and use network; that is very important. Also use the Trachtenberg school's alumni network. 